\title{
NUTRITIONAL CONDITION OF CHILDREN WHO BENEFIT FROM THE "BOLSA FAMÍLIA" PROGRAMME IN A CITY OF NORTHWESTERN SÃO PAULO STATE, BRAZIL
}

\author{
Fabiana Pelegrin Cogo dos Santos ${ }^{1}$, Fabiana Cristina Frigieri De Vitta², \\ Marta Helena Souza De Conti ${ }^{1}$, Sara Nader Marta ${ }^{1}$, Márcia Aparecida Nuevo Gatti ${ }^{1}$, \\ Sandra Fiorelli de Almeida Penteado Simeão ${ }^{1}$, Alberto De Vitta ${ }^{1}$
}

\begin{abstract}
Introdution: The direct income transfer programmes such as "BolsaFamília" have the important function of making it possible for aspects of life to receive the necessary care and importance in order to improve the quality of life. One of the aspects concerns food and healthy nutrition. Objective: The objective was to assess the nutritional condition of children under five years old whose families are benefited by the programme"BolsaFamília" in a city of northwestern São Paulo state, Brazil. Methods: A cross-sectional and retrospective study was carried out using the medical records of 284 children under the age of five, from which socio-demographic, weight and height data were collected. In order to diagnose children's nutritional condition, the indicators weight/age, height/age and weight/height were used, from the cutoffpoint z-score, recommended by the WHO Global Database on Child Growth and Malnutrition. Descriptive statistics and the Chi-square test were used to analyse data, assessing the association of indicators, gender and age. Results: $8.8 \%$ of the children have deficits concerning height/age and $4.2 \%$ have deficits concerning weight/age; $8.1 \%$ and $7.4 \%$ are overweight concerning weight/age and weight/height; $4.6 \%$ of the children under 2 years oldhave higher weight than the expected for their age and also for their height, and $7.8 \%$ of the children have low height for their age. The prevalence of weight deficit and excess in children observed in this study were similar to those found in other regions of Brazil. Conclusion: The maintenance of the nutritional surveillance system is extremely important in order to detect risk groups and help plan effective measures to prevent and correct nutritional problems.
\end{abstract}

Keywords: children's health, anthropometry, nutrition programmes and policies, nutritional assessment.

\section{INTRODUCTION}

The investigation of the nutritional condition of children and adolescents has been discussed in Brazil since the beginning of the $20^{\text {th }}$ century; social policies have been implemented in order to monitor and provide the recovery of the individuals' nutritional conditionas well as in order to fight against hunger-related issues.

Considering that an improvement of the financial situation of a family may lead to better nutritional conditions for their children, the Brazilian government has successfully implemented income transfer programmes, such as the "BolsaFamília" programme (BFP).

The BFP is a direct income transfer programme created in 2003 aimed at reducing poverty and inequalitiesand fighting against hunger in poor families (with monthly income per capita between $R \$ 60.01$ and $R \$ 120.00$ ) and in extremely poor families (with monthly income per capita of up to $R \$ 60.00$ ). In order to achieve that, three aspects are discussed: the immediate aid to reduce poverty bythe direct income transfer; the reinforcement of basic social rights concerning Health and Education; the coordination of complementaryprogrammes, in order for the families to be able to overcome the vulnerability and poverty condition ${ }^{1}$.

According to Cacciamali, Tatei and Batista ${ }^{2}$

the BFP is the biggest income transfer programme in Brazil, destined to families with little financial resources; it includes actions

1 Dentistry in Public Health, Universidade do Sagrado Coração (USC), Rua Ir. Arminda, 10-50, Jd Brasil, CEP: 17011-160; Bauru, SP, Brasil.

2 Department of Special Education, Universidade Estadual Paulista, Av. Hygino Muzzi Filho, 737, CEP 17525-900; Marília, SP, Brasil. Corresponding author: Alberto De Vitta. E-mail: albvitta@yahoo.com.br.

Suggested citation: Santos FPC, Vitta FCF, Conti MHS, Mata SN, Gatti MAN, Simeão SFAP et al. Nutritional condition of children who benefit from the "Bolsa Família" programme in a city of northwestern, São Paulo state, Brazil. Journal of Human Growth and Development. 25(3): 313-318. Doi: http://dx.doi.org/10.7322/jhgd.106003

Manuscript submitted Oct 22 2014, accepted for publication Dec 192014. 
to care for the health and nutritional condition of pregnant women and their children, ensuring children between the ages of 7 and 15 are enrolled at school and attend $85 \%$ of the classes, taking part in nutritional education programmes (p. 275).

Therefore, it is expected that the beneficiary is able to exercise their citizenship and behave as aneconomic agents, providing for themselves and their families, being part of a wider context of relationships, through which the effects of their poverty can be diminished ${ }^{2-5}$.

This programme has as premise the fulfilment of some requirements by the benefited families, such as the update of the vaccination schedule and the monthly follow up on the growth of children under 7 years old, as well as school attendance for children and adolescents between the ages of 6 and $17^{1}$. The objective is to increase the level of social rights that are effectively respected by inducing the supply and demand of health services, education and social assistance, breaking, therefore, the cycle of the continuous reproduction of poverty.

Concerning the prevalence ofanthropometric deficits, data obtained in the latest National Research of Demography and Health of Children and Women ("Pesquisa Nacional de Demografia e Saúde da Criança e da Mulher" - PNDS) from 2006 showed that amongst children under five years old, $7 \%$ had height deficit, $2 \%$ had weight deficit concerning height and $1.7 \%$ had weight deficit ${ }^{4,7}$.

Studies aiming at evaluating the nutritional condition of the children who are benefited from income transferprogrammes are extremely important due to the high investment of the government in social programmes, emphasising the BFP and the high expectations of the population in the improvement of life conditions and health, possibly made viable through these benefits.

Furthermore, in 1999, the National Policy of Food and Nutrition ("PolíticaNacional de Alimentação e Nutrição" - PNAN) which "means the commitment of the Health Ministry with the promotion of healthy eating habits and prevention and control of nutritional problems related to food and nutritionuncertainty", aiming at ensuring the right to food and health (p. 813) ${ }^{8}$. According to these authors, thePNAN has the following directives:

encouragement of intersectoral actions, aimed at the universal access to food; assurance of the quality of the food, as well as related services; monitoring of the nutritional condition; promotion of healthy eating habits and lifestyles; prevention and control of the nutritional disturbances and diseases related to eating habits and nutrition; promotion of the development of investigation lines; and the development and enabling of human resources (p. 813).

Considering the mentioned aspects, the objective of the present study was to evaluate the nutritional condition of children under five years old whose families are benefited from the "Bolsa-família" programme, in the town of Piratininga, São Paulo.

\section{MATERIAL AND METHODS}

A transversal study of all the 283 children who are under five years old, living in the town of Piratininga, and whose families are benefited from the "BolsaFamilia" Programme (BFP), was carried out.

According to data from the Brazilian Institute of Geography and Statistics ("InstitutoBrasileiro de Geografia e Estatística" - IBGE) ${ }^{9}$, the town in question has an area of $402 \mathrm{~km}^{2}$ and an estimated population of 10,584 in habitants. Also according to IBGE, in 2010 the town had three health centre sassisting the population through SUS - "Sistema Único de Saúde" (Brazilian Health care System).

The percentage of children is $14.4 \%$, being $13 \%$ under seven years old. The child mortality rate, considering children under 1 year old, is 14.11, the life expectancy is of 72.1 years, and the literacy rate is $90.35 \%$. The Gini index, which shows that the inequality levelin the incomedistribution is 0.44 ; and the Human Development Index (HDI) is 0.797.

In order to obtain the necessary data (age, gender, and current weight and height), the Health Department of the town provided a permit and, with the aid of a trained nurse, the data were collected and entered in a previously elaborated form, during the periodicvisit to the HealthCentreof each child who takes part in the BFP. The project has been approved by the Committee of Ethics in Research of the University SagradoCoração (prot. No. 123).

The birth date on the child's identification card was checked. The weight was obtained using scales that were revised and calibrated by the National Institute of Metrology ("InstitutoNacional de Metrologia" - INMETRO) - the governmental organization responsible for the maintenance. The height was measured with an anthropometer, tape measure and triangles. The children were weighed and measured with no shoes on, with nothing on their heads and wearing little clothing ${ }^{10}$.

In order to categorize the children regarding indicators of weight/age, weight/height and height/ age, cutoff points by z-score were used, as recommended by the WHO Global Database on Child Growth and Malnutrition ${ }^{11}$.

The cutoff points for weight concerning age for children are: < z-score - 3 (very low weight), $>$ z-score -2 and $<$ z-score +2 (correct weight) and $\geq$ z-score - 2 (high weight).

In order to analyse the height concerning age, the points are: < z-score -2 (low height) and $\geq z$-score - 2 (correct height). The points related to weight concerning height are: < z-score - 2 (low weight), $\geq$ z-score - 2 and z-score +2 (correct weight) and $\geq z$-score +2 (high weight).

The indicators were calculated using the software WHO Anthro, developed by the WHO to help monitor the growth and development of individuals and populations of children up to five years old.

The collected data wereentered in the software SPSS (version 16.0). The indicatorsof the nutritional condition were described by their absolute and relative frequencies and listed in tables. The Chi-square $(\chi 2)$ test was used in order 
to check the association between indicatorsof the nutritional condition and the age group (under two years old and between two and five years old $)^{12}$.

\section{RESULTS}

The social-demographic characteristics of the children showed that $50.5 \%$ were boys and $75.9 \%$ were under two years old.
It was observed that $4.2 \%$ of the children had deficits in the indicator weight/age and $8.8 \%$ had deficits in the indicator height/age, while $8.1 \%$ and $7.4 \%$ showed weight excess in the relation weight/age and weight/height, respectively (Table 1).

On Table 2 , it can be observed that $4.6 \%$ of the children under 2 years old showed high weight concerning the age and height, while $7.8 \%$ showed low height considering the age. The Chi-square test

Table 1: Distribution of the absolute and relative frequencies of the indicators of the nutritional condition of children who are benefited by the "BolsaFamília" Programme (Piratininga 2010)

$\begin{array}{lcc}\begin{array}{l}\text { Indicators of the } \\ \text { nutritional condition }\end{array} & \text { N } \\ \text { Weight concerning age } & 12 & 4.2 \\ \text { Low weight for the age } & 248 & 87.6 \\ \quad \text { Correct weight or eutrophic } & 23 & 8.1 \\ \text { High weight for the age } & 25 & 8.8 \\ \text { Height concerning age } & 258 & 91.2 \\ \quad \text { Low height for the age } & & 1.1 \\ \text { Correct height for the age } & 3 & 91.2 \\ \text { Weight concerning the height } & 259 & 7.4\end{array}$

for the indicators Weight/Age and Weight/Height showed statistical significance, suggesting there is an association between these indicators and the age group.

Table 2: Distribution of the absolute and relative frequencies of the indicators of the nutritional condition of children who are benefited by the "BolsaFamília" Programme concerning age group and respective statistic test (Piratininga 2010)

\begin{tabular}{|c|c|c|c|c|c|}
\hline \multirow{2}{*}{$\begin{array}{l}\text { Indicators of nutritional } \\
\text { conditions }\end{array}$} & \multicolumn{2}{|c|}{$<25$ months } & \multicolumn{2}{|c|}{$\geq 25$ months } & \multirow[t]{2}{*}{$\boldsymbol{p}$} \\
\hline & $\mathbf{n}$ & $\%$ & $\mathbf{n}$ & $\%$ & \\
\hline \multicolumn{6}{|l|}{ Weight concerning age } \\
\hline Low weight for the age & 9 & 3.2 & 3 & 1.1 & $p<0.05^{*}$ \\
\hline Correct weight or eutrophic & 191 & 67.5 & 57 & 20.1 & \\
\hline High weight for the age & 13 & 4.6 & 10 & 3.5 & \\
\hline \multicolumn{6}{|l|}{ Height concerning age } \\
\hline Low height for the age & 22 & 7.8 & 3 & 1.1 & $p>0.05$ \\
\hline Correct height for the age & 191 & 67.5 & 67 & 23.7 & \\
\hline \multicolumn{6}{|l|}{ Weight concerning the height } \\
\hline Low weight for the height & 2 & 0.7 & 1 & 0.4 & $p<0.05^{*}$ \\
\hline Correct weight or eutrophic & 198 & 70.0 & 61 & 21.6 & \\
\hline High weight for the height & 13 & 4.6 & 8 & 2.8 & \\
\hline
\end{tabular}

* Statistically significant

\section{DISCUSSION}

The present study had the objective of checking the nutritional condition of children under the age of five who take part in the "BolsaFamilia" programme in the town of Piratininga, SP, being important to highlight that the cutoff pointsfor each gender were considered in order to classify the nutritional condition.
The anthropometric characteristics of the studied group revealed that $4.2 \%$ and $8.8 \%$ of the children present deficits in the indicatorsweight/age and height/age, respectively. Results from the National Research of Demography and Health of Children and Women ("PesquisaNacional de Demografia e Saúde da Criança e da Mulher" - PNDS), carried out in 2006, showed that, amongst the children under five 
years old, $7 \%$ had height deficits, $2 \%$ had weight deficits concerning height and $1.7 \%$ had weight deficits concerning age ${ }^{13}$. In Rio de Janeiro, it was observed that $15 \%$ of the children had deficits in the indicator weight/age and $9.1 \%$ had deficits in the indicator height/age ${ }^{14}$.

Tumaet al. ${ }^{15}$ observed that $2.2 \%$ of the children had deficits in weight/age and $4.8 \%$ in height/age. Saldivaet al. ${ }^{16}$ observed a $4.3 \%$ deficit in the indicator weight/age and a $9.9 \%$ deficit in the indicator height/age, and Silva et al. ${ }^{17}$ observed deficit of $1.5 \%$ in the indicator weight/age and of $4.4 \%$ in the indicator height/age.

According to the follow up registered by the System of Food and Nutritional Surveillance ("Sistema de VigilânciaAlimentar e Nutricional" SISVAN) until June 2008, amongst the children under five who are benefited from the BFP in all the state of Minas Gerais, 5.6\% had low weight for their age (between the percentiles of 0.1 and 3), $6.7 \%$ had low weight for their height and $12.5 \%$ had low height for their age.

It was observed that $8.1 \%$ and $7.4 \%$ of the children from Piratininga had weight excess in the indicators weight/age and weight/height. Such results are compatiblewith the onesfound by Tumaet al. ${ }^{15}(6.9 \%$ and $6.1 \%)$ and Oliveira et al. ${ }^{18}(4.0 \%$ and $5.6 \%)$.

When the indicators are analysed concerning age groups, it is observed that $4.6 \%$ of the children who are under 2 years old had high weight concerning their age and high weight concerning their height, and $7.8 \%$ of the children had low height concerning their age. Aguiar ${ }^{19}$ observed that $10.9 \%$ of the children were over the expected weight, Verly Junior observed that $6.35 \%$ showed excess weight and Silva and Nunes ${ }^{21}$ observed that the overweight and obesity prevailed, respectively, in $14.8 \%$ and $9.1 \%$ of the females and in $16.1 \%$ and $11.9 \%$ in males.

In a national study carried out in Sobral, it was observed that $5.7 \%$ of the children who benefit from the programme showed deficit in weight and $12.8 \%$ showed deficit in height ${ }^{22}$. A similar research published by the Health Ministry found $10.7 \%$ children with low weight for their age, 2.2\% with low weight for their height and $15.1 \%$ with deficit in height ${ }^{23}$. Monteiro et al. ${ }^{24}$ observed that percentage of low weight considering age and height were $2.0 \%$ and $1.0 \%$, respectively, and only the percentage of low height $(6.3 \%)$ was higher than expected.

Concerning the children who had weight excess, one of the hypothesis to explain it may be in the context of the transition in eating habits experienced in the country, when there is an increase in the availability of industrialized foods, rich in calories and fat, and reduction in the intake of fruit and vegetables, followed by the increase of overweight and anaemia, reflecting incorrect eating habits ${ }^{1}$.

The results showed that the increase in the families' income through the BFP does not necessarily reflect an improvement in the nutritional condition of the benefited people. The concomitance of weight excess and malnutrition can be observed especially in the developing countries of Latin America. During the nutritional transition, overweight is highlighted as a national problem, while malnutrition is still a problem in some regions, especially the less developed ones, which points out to a close relationship between nutritional aggravation and development and income amongst the populations ${ }^{25}$.

Similar data were found by Figueroa Pedraza, Queiroz and Menezes ${ }^{26}$ who highlighted the importance of income transferprogrammes, such as the BFP, in order to ensure food and family safety, since what they found in the study they carried out was that the socio-economical condition is a determining factor for family safety.

However, a specific project to promote health is necessary, with strategies that integrate "actions in health and the understanding of the necessity of adopting a wider perspective of caring concerning the socio-politicalcontext people are in, as well as the local cultural peculiarities" (p. 53) ${ }^{27}$. Jaime et al. ${ }^{8}$ agree with that assessment and highlight that the governmental policies reflect that idea and there is legislation for such project to encourage healthy eating habits and care for nutrition.

Concerning healthy eating habits, the PNAN proposes the use of guides on eating habits, which would focus on each age group of the population, in addition to courses forpeople who want to become health professionals to act in Basic Assistance, considering the importance of their work regarding the early stages of a child's life, once the eating habits that are acquired in childhood reflect in other phases of the individual's life ${ }^{8}$.

Trevisani, Burlandy and Jaime ${ }^{5}$, analysing the conditionalsrelated to the BFP, point out the importance of the nutrition field. However, they highlight that

however the conditionals include basic actions in health, the technical documents from the Brazilian Government do not bring a deep discussion on how the health services can reorganize the working processes in order to ensure full attention to these families, therefore contributing to their effective inclusion in the SUS (p. 469).

Teixeiraet al. ${ }^{27}$ identified that $80 \%$ of the teams from the analysed regions (north, northeast, central-east, south and southeast) carry out "educational actions related to eating habits and nutrition, favouring healthier choices by the individuals and groups" (p. 64). Nevertheless, the authors point out a serious problem in the development of policies regarding income transfer - lack of information on the effectiveness of these interventions.

The lack of evaluation of the measures taken in relation to the BFP hinder the understanding of the effectiveness of the actions and their reorganization, i.e., the problems exist, as evidenced by the results mentioned above, but where do they occur, in which phase of the process?

Jaime et $a l .{ }^{8}$ analysed the difficulties and challenges concerning an efficient work regarding actions related to food and nutrition in Basic Assistance, amongst which, the ensured periodic 
evaluation of the nutrition condition of the populations.

Despite the fact that the BFP aims at improving life conditions, it depends on the "efficiency of the conditionals in order to prevent poverty from passing from one generations to another, i.e., the positive effect of the programme in the long term depends on the offer of better quality services concerning education and health" (p. 289) ${ }^{2}$. Jaime et al. ${ }^{8}$ report that the creation of Centresof Support to Family Health, as well as the work of nutritionistsin the teams, may help in the accomplishment of this task.

Finally, Martins et al. ${ }^{4}$ systematically analysed studies aimed at evaluating the impact of income transferprogrammes on eating habits and nutrition of the people who benefit from them. They found studies that indicate a positive association between receiving the benefits and the improvement in the families' diets. However, they highlight that these programmes were implemented before the planned evaluation phase and use impact indicators, but not indicators of the process (offer, use and coverage)" (p. 1169), being possible for these studies to present evaluation problems. According to the authors, analysing the process may help in the identification of flaws in the programmes, indicating possible needs to change the way they are carried out.

Many of the mentioned authors reinforce the importance of the BFP for the income distribution and the minimization of the inequality consequences it causes. Never the less, they high light the importance of the quality of these services $2,4,5,8,26$.

\section{REFERENCES}

1. Wolf MR, Barros Filho AA. Estado nutricional dos beneficiários do Programa Bolsa Família no Brasil - uma revisão sistemática. Ciênc Saúde Coletiva. 2014; 19(5):1331-8. DOI: http:// dx.doi.org/10.1590/1413-81232014195. 05052013

2. Cacciamali MC, Tatei F, Batista NF. Impactos do programa bolsa família sobre o trabalho infantil e a frequencia escolar. RevEcon Contemp. 2010; 14(2): 269-301. DOI: http://dx.doi.org/ 10.1590/S1415-98482010000200003

3. Oliveira AS, Crispim AB, Liberalino LCP. Desmistificando o programa bolsa família: impactos na vida e no estado nutricional dos beneficiários. Rev Científica Escola Saúde. 2014; 4(1): 17-31.

4. Martins APB, Canella DS, Baraldi LG, Monteiro CA. Transferência de renda no Brasil e desfechos nutricionais: revisão sistemática. Rev Saúde Pública. 2013; 47(6): 1159-71. DOI: http:/ /dx.doi.org/10.1590/S0034-8910.20130 47004557

5. Trevisani JJD, Burlandy L, Jaime PC. Fluxos decisórios na formulação das condicionalidades de saúde do Programa Bolsa Família. Saúde Soc. 2012 ; 21(2): 492-509. DOI: http://dx.doi. org/10.1590/S0104-12902012000200021

6. Oliveira SM, Santos GR, Rosa TRS, Oliveira CL. Condicionalidades e proteção social no programa bolsa família. Rev Desenvolvimento Social. 2013; 1(9): 15-23.

\section{CONCLUSION}

In the studied sample, it was observed that the children had deficits in the indicators weight/ age and height/age with concomitantweight excess. This scenario points out to the need of maintenance of a system of nutritional surveillance capable of detecting risk groups and helping in the creation of efficient measures to prevent and correct nutritional problems.

Therefore, the follow up performed by the professionals from Basic Assistance onthe people who benefit from the "BolsaFamília"Programme represents a great effort to eradicate the fragilityand poverty situation, including actions concerning education for children and their families, aiming at the prevention and correction of nutritional problems.

Such interventions may promote communication in the health system, allowing professionals to understand the social and cultural variables of the assisted population in a way that the proposed actions may be effective. There is a need of surpass the health assistance model that is only concerned about biological risk, proposing communityaction strategies that unite the health aspect tosocial and educational ones.

Therefore, what was mentioned above is the only possible way to improve the life quality of the people who benefit from the programme, not only increasing their income or the amount of food they can afford, but also increasing their awareness about being responsible for the actions that can potentially lead to a healthy life.

7. Brasil. Ministério da Saúde. Manual de orientações sobre o Bolsa Família. Brasília: Ministério da Saúde; 2005.

8. Jaime PC, Silva ACF, Lima AMC, Bortolini GA. Ações de alimentação e nutrição básica: a experiência de organização no governo Brasileiro. Rev Nutr. 2011; 24(6): 809-24.

9. Instituto Brasileiro de Geografia e Estatística (IBGE). Estimativas, projeções e populações de 2010. [cited 2011 Fev 05] Available from: http:/ /www.ibge.gov.br/estadosat/perfil.php?sigla =rj

10. World Health Organization (WHO). Physical status: the use and interpretation of antropometry: report of a WHO Expert Committee. Geneva: The Organization; 1995.

11. World Health Organization (WHO). Child growth standards. Length/height-for-age, weight-forage, weight-for-length, weight-for-height and body mass index-for-age: methods and development. Geneva: World Health Organization; 2006.

12. Zar JH. Biostatistical Analysis. $5^{\text {th }}$. ed. New Jersey: Prentice-Hall. 2010.

13. Brasil. Centro Brasileiro de Análise e Planejamento. Pesquisa Nacional de Demografia e Saúde da Criança e da Mulher: PNDS 2006. Brasília: Ministério da Saúde; 2009.

14. Santos ALB, Leão LSCS. Perfil antropométrico de pré-escolares de uma creche em Duque de Caxias, Rio de Janeiro. Rev Paul Pediatr. 2008; 26(3): 218-24. DOI: http://dx.doi.org/ 10.1590/S0103-05822008000300004

15. Tuma RCFB, Costa THM, Schmtiz BAS. Avaliação antropométrica e dietética de pré-escola- 
res em três creches de Brasília, Distrito Federal. RevBras Saúde Matern Infant. 2005; 5(4): 419-28. DOI: http://dx.doi.org/10.1590/ S1519-38292005000400005.

16. Saldiva SRDM, Silva LFF, Saldiva PHN. Avaliação antropométrica e consumo alimentar em crianças menores de cinco anos residentes em um município da região do semiárido nordestino com cobertura parcial do programa bolsa família. Rev Nutr. 2010; 23(2): 221-29. DOI: http://dx.doi.org/10.1590/S1415-527320 10000200005

17. Silva MC, Capanema FD, Lamounier JA, Silva ACA, Oliveira BM, Rodrigues J. Perfil Nutricional de crianças pré-escolares em creches públicas de Belo Horizonte - Minas Gerais beneficiárias ou não do Programa Bolsa Família. Percurso Acadêmico. 2014; 4(7): 88-104.

18. Oliveira MCF, Silva PL, Mesquita MA. Analisando o padrão alimentar e o estado nutricional de pré-escolares matriculados na creche do município de Descoberto, MG. RevNutr Brasil. 2006; 5(3): 150-9.

19. Aguiar NA. Perfil do estado nutricional de crianças de zero a sete anos beneficiárias do programa bolsa família no período de 2008 e 2009 no município de Paulista-PE. Monografia - Centro de Pesquisas Aggeu Magalhães. Recife: 2010.

20. Verly Junior E, Bronhara B, Fernandes MCS, Lima CAM. Diagnóstico nutricional de crianças de zero a cinco anos atendidas pela Rede Pública Municipal de Saúde de Ouro Preto-MG. NutrireRevSocBrasAliment Nutr. 2008; 33(3): 71-81.

21. Silva DAS, Nunes HEG. Prevalência de baixo peso, sobrepeso e obesidade em crianças pobres do Mato Grosso do Sul. RevBrasEpidemiol. 2015; 18(2): 466-75. DOI: http://dx.doi.org/ 10.1590/1980-5497201500020014

22. Peres EC, Freitas CASL. Estado nutricional dos beneficiários do programa bolsa família no município de Sobral, Ceará, Brasil. Sanare: Rev Políticas Públicas. 2008; 7(1): 56-63.
23. Brasil. Ministério da Saúde. Secretaria de Atenção à Saúde. Departamento de Atenção Básica. Avaliação do Programa Bolsa-Alimentação: primeira fase. Brasília: Ministério da Saúde; 2004.

24. Monteiro CA, Benício MHD, Konno SC, Silva ACF, Lima ALL, Conde WL. Causas do declínio da desnutrição infantil no Brasil, 1996-2007. Rev Saúde Pública. 2009; 43(1): 35-43. DOI: http:/ / d x . d o i . org/10.1590/S0034 89102009000100005

25. Ferreira VA, Silva $A E$, Rodrigues CAA, Nunes NLA, Vigato TC, Magalhães R. Desigualdade, pobreza e obesidade. Ciênc Saúde Coletiva. 2010; 15(suppl1): 1423-32. DOI: http:// dx.doi.org/10.1590/S1413-81232010000 700053

26. Pedraza DF, Queiroz D, Menezes TN. Segurança alimentar em famílias com crianças matriculadas em creches públicas do Estado da Paraíba, Brasil. Rev Nutr. 2013; 26(5): 51727. DOI: http://dx.doi.org/10.1590/S141552732013000500003

27. Teixeira MB, Casanova A, Oliveira CCM, Ensgtrom EM, Bodstein RCA. Avaliação de práticas de promoção da saúde: um olhar das equipes participantes do Programa Nacional de Melhoria do Acesso e da Qualidade da Atenção Básica. Saúde Debate; 2014; 38(spe) : 52-68. DOI: http://dx.doi.org/10.5935/0103-1104. 2014S005

Justification for publishing the article: Nutritional condition of children who are benefited from the "bolsafamília" programme. The article allows and enriches the discussion, which is still scarce in the country, on the interference of the "bolsafamilia"programme in the eating habits and nutrition of children under the age of five. It contributes with data that allow the government to effectively create programmes aimed at improving the food intake patterns and the children's nutritional condition.

\section{Resumo}

Introdução: os programas de transferência direta de renda, como o Bolsa Família têm a importante função de possibilitar que aspectos da vida cotidiana recebam o cuidado e importância necessários para a melhoria da qualidade de vida. Um deles diz respeito à alimentação e nutrição saudável. Objetivo: o objetivo foi avaliar o estado nutricional em menores de cinco anos, cujas famílias são beneficiadas pelo programa "Bolsa-família" de uma cidade da região noroeste do estado de São Paulo. Método: para tal, foi realizado um estudo retrospectivo e transversal com os prontuários de 284 crianças menores de cinco anos de idade, dos quais foram coletados dados sócio-demográficos, de peso e altura. Para o diagnóstico nutricional das crianças foram utilizados os indicadores Peso/ Idade, Estatura/Idade e Peso/Estatura, a partir do ponto de corte por escore-z, recomendados pela WHO Global Database on Child Growth and Malnutrition. Para a análise dos dados foram utilizados os recursos da estatística descritiva e o teste de Qui-quadrado para verificar associação entre os indicadores, o sexo e a faixa etária. Resultados: do total de crianças $8,8 \%$ apresentam déficits no indicador estatura/idade e $4,2 \%$ no peso/idade; $8,1 \%$ e $7,4 \%$ excesso de peso na relação peso/ idade e peso/estatura; $4,6 \%$ das crianças menores de 2 anos apresentaram peso elevado para idade e peso elevado para a estatura e $7,8 \%$ dessas crianças apresentaram baixa estatura para idade. A prevalência de déficit e excesso de peso população infantil observada neste trabalho foi semelhante às encontradas em outras regiões do Brasil. Conclusão: é necessário a manutenção do sistema de vigilância nutricional capaz de detectar os grupos de risco e auxiliar na formulação de medidas eficientes para prevenção e correção dos problemas nutricionais.

Palavras-chave: saúde da criança, antropometria, bolsa família, avaliação nutricional. 